Meta

Journal des traducteurs

Translators' Journal

\title{
Use of Extralinguistic Knowledge in Translation
}

\section{Ryonhee Kim}

Volume 51, numéro 2, juin 2006

Théories et pratiques de la traduction et de l'interprétation en Corée

Theories and Practices of Translation and Interpretation in Korea

URI : https://id.erudit.org/iderudit/013257ar

DOI : https://doi.org/10.7202/013257ar

Aller au sommaire du numéro

\section{Éditeur(s)}

Les Presses de l'Université de Montréal

\section{ISSN}

0026-0452 (imprimé)

1492-1421 (numérique)

Découvrir la revue

\section{Citer cet article}

Kim, R. (2006). Use of Extralinguistic Knowledge in Translation. Meta, 51(2), 284-303. https://doi.org/10.7202/013257ar

\section{Résumé de l'article}

Quand un traducteur compétent interprète un texte qu'il doit traduire, il a souvent recours à la stratégie d'inférence. Il semble aussi que, dans cette phase de compréhension, les connaissances extralinguistiques du traducteur jouent un rôle crucial. Cependant, nous ne savons pas encore quelle est l'importance de ces connaissances extralinguistiques par rapport à d'autres éléments constituant la compétence pure de traduction et en quoi elles jouent un rôle aussi considérable. Cet article a pour but d'étudier, à partir des données obtenues grâce à un questionnnaire et au TAP (Thinking Aloud Protocol), le rôle des connaissances extralinguistiques au moment de la compréhension dans la traduction L1 $\rightarrow$ L2. les traducteurs professionnels, des apprentis traducteurs (semi-traducteurs) et des étudiants apprenant la langue étrangère ont participé à cette enquête. Le résultat des analyses illustre bien que : (i) l'utilisation active des connaissances extralinguistiques améliore la concision et l'efficacité des inférences des traducteurs, et augmente la qualité de la traduction ; et (ii) « L'effort de traduction " peut compenser l'insuffisance de compétences linguistiques et extralinguistiques. Le traducteur devrait donc avoir un large éventail de connaissances générales et spécialisées pour produire une traduction de qualité. De plus, il doit garder à l'esprit que plus intenses sont l'effort et la motivation, meilleure sera la traduction finale.
Ce document est protégé par la loi sur le droit d'auteur. L'utilisation des services d'Érudit (y compris la reproduction) est assujettie à sa politique d'utilisation que vous pouvez consulter en ligne.

https://apropos.erudit.org/fr/usagers/politique-dutilisation/ 


\title{
Use of Extralinguistic Knowledge in Translation
}

\author{
RYONHEE KIM \\ Dongduk Women's University, Seoul, Korea \\ kryon@dongduk.ac.kr
}

\section{RÉSUMÉ}

Quand un traducteur compétent interprète un texte qu'il doit traduire, il a souvent recours à la stratégie d'inférence. Il semble aussi que, dans cette phase de compréhension, les connaissances extralinguistiques du traducteur jouent un rôle crucial. Cependant, nous ne savons pas encore quelle est l'importance de ces connaissances extralinguistiques par rapport à d'autres éléments constituant la compétence pure de traduction et en quoi elles jouent un rôle aussi considérable. Cet article a pour but d'étudier, à partir des données obtenues grâce à un questionnnaire et au TAP (Thinking Aloud Protocol), le rôle des connaissances extralinguistiques au moment de la compréhension dans la traduction $\mathrm{L} 1$ à L2. Des traducteurs professionnels, des apprentis traducteurs (semi-traducteurs) et des étudiants apprenant la langue étrangère ont participé à cette enquête. Le résultat des analyses illustre bien que: (i) I'utilisation active des connaissances extralinguistiques améliore la concision et l'efficacité des inférences des traducteurs, et augmente la qualité de la traduction; et (ii) «L'effort de traduction» peut compenser l'insuffisance de compétences linguistiques et extralinguistiques. Le traducteur devrait donc avoir un large éventail de connaissances générales et spécialisées pour produire une traduction de qualité. De plus, il doit garder à l'esprit que plus intenses sont l'effort et la motivation, meilleure sera la traduction finale.

\section{ABSTRACT}

A competent translator seems to make extensive use of inferential strategies in the process of understanding a source text in translation. It also appears that extralinguistic knowledge plays an important role in this inference. However, it has not been determined how important it is relative to other components of translator competence and in what way it is important. This study investigated the use of extralinguistic knowledge in comprehension processes by analyzing data from $L_{2} \rightarrow L_{1}$ translation, a questionnaire and a think-aloud study. Professional translators, translation students (or semi-professionals), and language learners participated in the study. Major (albeit tentative) findings are the following: (i) The use of extralinguistic knowledge that is most relevant for a specific translation problem makes the inferential process more concise and efficient and it leads to a higher-quality translation; (ii) "Translation effort" can compensate for overall lack of linguistic and extralinguistic competence in translation. It is suggested that a translator needs to have a broad base of specialized knowledge as well as world knowledge. Also, $\mathrm{s} /$ he should bear in mind that the greater the effort or involvement with the translation, the better the output.

\section{초록}

번역과정에서 원문을 이해하기 위해서는 추론전략이 동원되며, 언어외적 지식은 이 러한 추론과정에서 중요한 역할을 한다. 본고에서는 전문번역사, 번역학습자, 언어 학습자를 대상으로 한 L2->L1번역, 설문조사, 사고발화연구를 통해 이해과정에서의 언어외적 지식의 역할을 살펴보았다. 연구결과 번역문제 해결에 적절한 언어외적 지식이 있다면 보다 간결한 번역과정을 통해 더욱 효율적으로 양질의 번역을 할 수 있음을 알 수 있었다. 또한 “번역노력”은 언어적/언어외적 지식의 결함을 극복할 수 있는 중요한 번역능력의 요소임이 밝혀졌다. 번역사는 보다 광범위한 분야에 관 
심을 갖고 일반지식은 물론 전문지식을 갖출 수 있도록 평소 꾸준한 노력을 기울 여야 하며, 무엇보다도 번역에 임하는 자세가 보다 진지하고 성실해야 할 것이다.

MOTS-CLÉS/KEYWORDS

translator competence, comprehension, inferences, extralinguistic knowledge, specialized knowledge

\section{Introduction}

A translator draws on all kinds of knowledge while translating, and such knowledge falls broadly under two types: linguistic and extralinguistic ${ }^{1}$. In addition, s/he must be equipped with translation methodology, i.e., knowledge and skills involving problem identification, problem-solving, decision-making, subject research skills, etc. A translator's competence might also involve self-concept, aptitude and personality, attitudes and affective factors (Laukkanen 1996), translation effort, understanding of translation, etc. Moreover, since these components of translator competence appear to complement each other, a translator who is lacking in one component or another can resort to other component(s) to compensate for that lack.

The overall competence level of a translator correlates with the overall quality of translation. However, it does not mean that each component contributes equally to improving the final output. There might be a hierarchy among them, meaning that some components might be more important than others in determining the quality. Given the fact that most translation work involves more or less specialized texts, it is likely that extralinguistic knowledge, rather than linguistic competence itself, plays a major role in the success of translation. For example, a scientist can translate a scholarly scientific article better than a professional translator who has little or no scientific knowledge. In this case, scientific knowledge, rather than the languages involved, becomes a major factor influencing the product. Lehmann (1986: 140) echoes this point:

One necessary prerequisite for successful comprehension is knowledge. For textual comprehension the type of knowledge available and how it is structured is more important than what language the subject speaks. Therefore, a professor of literature reading a translation of "À la recherche du temps perdu" might understand Proust better than a French wine merchant reading the original text.

Indeed, previous studies found that successful translation is characterized by the extensive use of extralinguistic knowledge together with linguistic knowledge (Tirkkonen-Condit 1988, 1989, 1992; Jääskeläinen 1990 cited from Tirkkonen-Condit 1992). On the other hand, unsuccessful translation tends to be linguistically oriented. Research findings support the predominance of extralinguistic knowledge over linguistic knowledge in the translation process. However, no close examination has been made on this subject.

Questions can arise as to how important extralinguistic knowledge is and how it is used in translation processes, or in what way it is important. To illustrate, a translator cannot translate successfully without understanding a source text (hereafter, ST). And s/he is very likely to come across comprehension problems (of various sorts and in varying degrees) at one point or another. There seem to be two major strategies used in solving comprehension problems: one is inferencing and the other is the use 
of reference books (Krings 1986: 270). Let's say that a translator does not know an ST item (lack of linguistic competence). S/He can infer meaning or refer to a dictionary (use of translation methodology). Here, one cannot say for sure whether inferencing as a comprehension strategy is superior to the use of dictionaries. However, studies suggest that excessive and unguided use of dictionaries, especially bilingual dictionaries, is not desirable (Tirkkonen-Condit 1989; Fraser 1993). Which strategy to use, or which to use first, depends largely on whether or not the relevant knowledge is available.

Knowledge used in comprehension can be classified into linguistic knowledge and extralinguistic knowledge. The type of knowledge used seems to determine the level of comprehension that can be reached, which ultimately affects the product quality. Dancette (1997: 94) posits three levels at which comprehension operates in translation: linguistic level, textual level, and notional level. His study shows that a translator who can conceptualize 'contextual' meaning at the notional level based on linguistic and extralinguistic knowledge can translate more successfully and creatively. On the other hand, a translator who remains at the linguistic and textual levels and fails to fully access the notional level (perhaps, with no extralinguistic knowledge) tends at best to find the 'literal' meaning and ends up with less successful translation. This study indicates that extralinguistic knowledge is important in the construction of comprehension because it enables a translator to comprehend a text at deeper, notional levels. ${ }^{2}$

The above discussion suggests that the availability and the use of extralinguistic knowledge is a major factor in determining the quality of the translation product. Specifically, extralinguistic knowledge seems to precede linguistic knowledge in its contribution to translation: it makes it possible for a translator to infer meaning at cognitive levels, leading to in-depth comprehension and thus successful translation. Studies on extralinguistic knowledge are too limited to draw any conclusions, however. Further studies are in order, and the present study attempts to investigate the status and the role of extralinguistic knowledge in translation. Research questions are posed as the following:

(1) How important is extralinguistic knowledge relative to other components or elements of the translator competence?

(2) How is extralinguistic knowledge used or in what way is it important in understanding an ST?

Research focuses on comprehension processes, and research design has been tailored to the questions posed: the translation is from L2 into L1 and the ST was rather difficult, with some specialized terms on economics and a few metaphorical expressions. The research uses three types of data from a translation, questionnaire, and think-aloud study. Translator competence can be measured by testing subjects. Alternatively, information can be gathered through a questionnaire by asking them relevant questions. How extralinguistic knowledge is used in the translation process can be investigated via a think-aloud method. The ultimate goal of the present study is to identify strategies and/or behaviors that are likely to lead to successful translation, and can be recommended for later use. In corollary, it is also to avoid those strategies and/or behaviors that could lead to unsuccessful translation. Thus, it reports on whatever is noteworthy in the two types of translation. 


\section{Research Design}

\subsection{Subjects}

Participants in the study included five professional translators (the Pro group), eleven translation students (the TS group), and twenty-one language learners (the LL group), all native speakers of Korean. The professional translators had four to thirteen years of translating experience at the time of the task. The translation students were studying translation at the Graduate School of Translation and Interpretation, Hankuk University of Foreign Studies (HUFS) in Korea. (Six of them had some translation experience, ranging from six months to five years, and could be termed semi-professionals.) The language learners were college seniors who had taken the course "Introduction to Interpretation and Translation" and had volunteered for the task.

Among the subjects, only three subjects took part in the think-aloud study, each representing the three groups. (hereafter, termed Pro, TS, LL for the groups they represent) Pro had eleven years of experience, TS had two years, and LL had none. Pro's English level was both advanced and sophisticated, TS had a fairly good command of English, and LL was far behind the other subjects. Pro specialized in the translation of scholarly papers, advertisements, and culture-related texts. TS had worked as a full-time translator at a financial institute for about a year, and s/he was quite familiar with texts such as the ST used in the study (as will be seen later). Pro had an advantage in relation to translation experience, whereas TS had the upper hand in relation to the subject matter (the ST was about the euro). LL, on the other hand, had much less knowledge in both English and the subject matter.

\subsection{Text}

The English ST selected was an article from England's main financial newspaper Financial Times issued on June 3, 1999 (see Appendix 1). The entire text was given to the subjects, but only the shaded part was to be translated. The text, whose topic was the weakness of the euro, was chosen because it posed potential semantic translation problems. The text was fairly difficult, and understanding it required specialized knowledge in economics; in particular, terms such as imported disinflation. A few metaphorical expressions also contributed to increasing the difficulty level of the text: they included concentrate minds, brush aside, power ahead, and spluttering. It was predicted, therefore, that the subjects would face mostly comprehension problems rather than production problems.

\subsection{Method}

The subjects translated the English text into Korean, their mother tongue. They were allowed to take the text home and use whatever resources were available and there was no time limit for the task. In addition to the final products, other forms of data collected were a questionnaire ${ }^{3}$ (see Appendix 2) and information recorded as per the think-aloud method. All the participants completed the questionnaire, while three subjects participated in the think-aloud study. The task descriptions for the translation and a questionnaire were given to the subjects in written form, and instructions for the think-aloud task were given orally. 
The questionnaire was used in two ways: first, to measure the subjects' overall translator competence (see I in Appendix 2) and second, to gather information about their problems and problem-solving processes or strategies (see II and III in Appendix 2 ). The subjects were instructed to complete the questionnaire after doing the translation. It might be that the amount of time between the translation work and the questionnaire varied considerably from one individual to another. Some might have done it immediately after the translation and others hours or even days after the translation. Consequently, the data collected via questionnaire may be 'retrospective' in some cases, while in other cases it may have relied upon the subjects' relatively long-term recall of the translation process. The think-aloud method was used because it offered a concurrent account of translation processing, and provided a reliable way to investigate extralinguistic knowledge as it was actually being thought through.

\section{Results}

\subsection{Results of the Questionnaire}

\subsubsection{Group performance}

The subjects' translations have been evaluated separately on a five-point scale by the researcher for 1) the sense conveyed and 2) the form in the target language, but the sense-based evaluation is used here for comparison. The sole use of semantic accuracy is quite appropriate given that the study focuses on comprehension, and difficulties involving comprehension rather than production have been anticipated. (Table 1 provides evaluation criteria.) It turned out that translation error was most often seen in three problematic sentences (second, fifth and seventh sentences).

TABLE 1

Criteria for Rating Translations on a Five-Point Scale

\begin{tabular}{|cl|}
\hline Scale rank & \multicolumn{1}{c|}{ Description } \\
\hline 1 & totally unacceptable translation \\
2 & poor translation requiring major improvements \\
3 & marginally adequate translation with several minor errors or one major error \\
4 & good translation with one minor semantic error \\
5 & perfect translation with no semantic errors \\
\hline
\end{tabular}

The average evaluation scores are provided in the column labeled "Sense" in Table 2. No marked difference is evident between the Pro group and the TS group. On the other hand, the LL group shows a much lower average score than the other two groups. There seem to be some individual differences in the Pro group: two subjects received scores of 5 , two received 4 , and one received 3 . Little variability was found among the subjects for the TS group: four received 5 and the rest, 4 . Greater individual differences were found among the LL group: two received 5, two received 4 and two received 3. About two-thirds of the LL participants scored 1 or 2.

For the questionnaire, the subjects were asked to rate themselves on their competence (as reflected in the five categories in Question I in Appendix 2). Points have been added up and averaged out by group for each of the five categories. Results are also shown in Table 2. First, in terms of Current Affairs (CA), Subject Matter 
Knowledge (SM), and Vocabulary (Voc), there was little or no difference between the Pro and TS groups. The LL group, however, obtained much lower average points (lower than the midpoint ' 3 ') than the two groups. This indicates that on the whole, the language learner subjects were not as interested in current affairs, were unfamiliar with the subject matter, and had little knowledge of terminology in the article.

TABLE 2

Evaluation of Translation and Self-Rated Competence of Subjects

\begin{tabular}{|l||c|c|c|c|c|c|c|}
\hline Group & Sense & Form & CA & SM & Voc & Eff & UT \\
\hline \hline Pro & 4.2 & 4.2 & 4.0 & 3.6 & 3.4 & 3.6 & 4.6 \\
\hline TS & 4.7 & 3.9 & 3.4 & 3.5 & 3.3 & 2.5 & 3.0 \\
\hline LL & 1.6 & 1.9 & 2.6 & 2.2 & 2.7 & 3.9 & 3.4 \\
\hline
\end{tabular}

(CA: interest and knowledge in current affairs; SM: knowledge about subject matter; Voc: vocabulary knowledge; Eff: translation effort; UT: understanding of translation)

${ }^{*}$ The total score is 5 for each category.

As regards the other two categories, Translation Effort (Eff) and Understanding of Translation (UT), it is noteworthy that the Pro group rated themselves excellent in UT, scoring 4.6. It might be that they were able to understand the nature of translation as a result of years of experience and research. It can also be noted that the LL group rated themselves high (3.9) for Translation Effort. It might be that they put a lot of effort to the translation work in order to compensate for their overall lack of competence. This contrasts with the performance of the TS group, who didn't seem to make much effort (as evidenced by their score, 2.5).

When viewed in relation to the final translation product, the results of the questionnaire indicate that deficiencies in knowledge in current affairs, subject matter, and vocabulary led to the lower translation quality. On the other hand, translation effort and understanding of translation did not markedly contribute to overall higher quality of translation. This, however, reflects group performance. It would be difficult to generalize the results across the subjects due to rather high levels of inter-subject variability. Therefore, close examination of individuals is needed here for the sake of higher validity. What follows is a report on a separate examination of those who achieved a perfect translation. What made them so successful is of major interest here.

\subsubsection{Individual performance}

The two professionals in the Pro group who achieved a score of 5 on their translations thought that they specialized in economics and finance in their translation. In the questionnaire, one of them marked 5 (a perfect score) in four of the five categories (except Translation Effort). A close examination showed that this subject had no difficulty understanding the ST, and there were no problematic segments whatsoever. Perhaps his ease in translating accounts for his perceived lack of effort, as indicated by giving himself a " 3 " for Translation Effort. The other subject seemed to have made extra effort in translating, even asking an expert about one problematic segment (imported disinflation). This is in sharp contrast with the performance shown by one professional in the same group: this subject marked 3 for Translation Effort and scored 3 (lowest in the group) for his translation. His idea of an experimental (as 
opposed to real-life) task and tight schedule might have affected his motivation to perform the task. As for those four subjects in the TS group, there was nothing remarkable about them compared to the rest in the same group.

For the two subjects in the LL group who distinguished themselves by scoring 5 on their translations, they didn't know a number of the terms (as shown by 2 and 3 for Voc) and had little knowledge about the subject matter (as shown by 1 and 2 for SM). However, they exerted a great deal of effort in their translation tasks (they marked 4 and 5 for Translation Effort). They also said that they had read their translation ten times or more and had made corrections (ten for one subject and "countless" corrections for the other subject) before submitting the final products. In total, they spent three and five hours, respectively, doing the task. In addition, a detailed examination of their problem-solving behaviors/strategies showed that they were deeply involved with the task. They consulted every resource available including dictionaries, encyclopedia, news articles (in English and Korean) dealing with the subject matter, parallel Korean texts, acquaintances with expert knowledge, etc. It is quite surprising that they delivered the message accurately in spite of relatively lower English proficiency and little specialized knowledge in the subject matter.

The results above suggest that knowledge about the subject matter (a type of extralinguistic knowledge) and translation effort are the two most important factors that affect the final translation product. To be specific, one can come up with a good translation without much time and effort if s/he is familiar with the subject matter of an ST. Also, one can anticipate a good translation without familiarity with the subject matter if s/he devotes a great deal of time and effort to translating.

\subsubsection{Translation problems}

In the questionnaire, the subjects were asked to check the problematic segments (see III in Appendix 2). ${ }^{4}$ It turned out that the average number of potentially problematic segments was 3.8. 3.1, and 5.1 for the Pro, TS, and LL groups, respectively. This means that the LL group has the most difficulty translating the text, followed by the Pro group and the TS group. The segments found to be problematic across groups included imported disinflation, export its way out of trouble, brush aside, powers ahead, concentrate minds, and should. These problems can be classified into three types: the first concerning specialized knowledge (imported disinflation, export its way out of trouble), the second metaphors (brush aside, powers ahead, concentrate minds), and the third grammar (should). The three groups coincided in the most problematic segment, imported disinflation, which required knowledge of economics.

As problematic segments do not necessarily lead to translation error, translations of the problematic segments were checked for accuracy and adequacy. Most translation errors were detected in the segment export its way out of trouble across groups. It can be noted that the segment which has been identified as the most problematic one (imported disinflation) and the segment which has actually turned out to be the most difficult one (export its way out of trouble) had something in common: for interpretation, they both required some specialized knowledge of economics. The difficulty of the translation seemed to be associated with the inaccessibility of specialized knowledge or background knowledge about the subject matter. This supports the observation made earlier that knowledge about the subject matter is a major element in determining the quality of the product. 
The grammatical problem should is ambiguous as it could mean either "had better" (necessity or obligation) or "probably" (certainty). Those who have such grammatical knowledge should have identified the segment as potentially problematic. Only one subject in the Pro group and about half the subjects in each of the other two groups did so. The final translation shows that three in the Pro group, three in the TS group, and all in the LL group got it right by translating it as meaning "necessity." The ability to identify potential translation problems and the capacity to produce accurate translation should be two separate elements. At any rate, the problem of should cannot be solved within the boundary of the text to be translated. The meaning can only be disambiguated using information from the rest of the text. Clues can be found in these two sentences: It is now time for the politicians, not the bankers... and At today's summit, EU leaders should...

\subsection{Results of the Think-Aloud Study}

A comparison of the three subjects has been made in terms of general translation behaviors, problem-solving strategies, and the use of dictionaries. The subjects differed along a few dimensions, which are reported below.

\subsubsection{General translation behaviors}

The subjects began their tasks somewhat differently. Pro started out by taking into consideration the source and publication date of the ST and the type of the target text. She then attempted to translate the title and to read the text silently. TS said that she would read the whole text first and started reading silently, which took about one minute. LL sat in front of her computer with three sites open on the monitor (an English-Korean dictionary, a Korean-English dictionary, and a search engine) and started translating the title right away (by looking up the word sagging in the dictionary) before reading the text aloud. Pro mentioned while reading the text that there were some parts she could not understand, and after reading she ventured a guess on the main point of the text. TB commented that the text would not be so difficult to translate, since the subject matter was somewhat familiar to her from her previous reading of similar texts. In contrast, LL said that it would be quite difficult to translate the text.

Pro proceeded through the text translating sentence by sentence rather spontaneously except the fifth sentence beginning with "While the U.S..." Since her translation was rather automatic and she did not verbalize her thoughts, not much information could be obtained about the internal processing. For the problematic sentence, however, she spent a fair amount of time with it, trying to extract meaning from the text. She didn't seem to care much about her target renderings throughout. Either she was preoccupied with the problematic sentence, or she was simply not verbalizing it due to automatic processing.

As for $\mathrm{TB}$, very little was recorded as she did not verbalize much of the time, perhaps as a result of automatic processing. Only a small portion of the translation processes or behaviors manifested themselves in the recording of this subject. The recorded parts allowed the researcher to observe and infer a few things about the process. It seems that the subject verbalized only when she encountered items she could not translate immediately. As she herself had expected at the outset, she didn't 
seem to have much difficulty understanding the ST. Her comprehension problems were restricted to a few items. She solved the problems through inferring and reasoning, using prior knowledge and information from the text. She seemed to pay a lot more attention to the way her translation was rendered. She actually said that her translation should flow naturally and that she needed to use "fancy" expressions since the translation was going to be published in a Korean current affairs magazine. In a word, she was conscious about coherence and stylistic and text-type adequacy as was observed in professional translators (Lörscher 1993).

LL actually struggled with the text, as evidenced by the sheer amount of time spent translating and recording (about one hour and forty minutes compared to forty minutes for Pro and thirty minutes for TS). Her performance was a typical example of word-for-word translation, and it was quite evident that translating the ST, with all the difficult terms and expressions, was simply beyond her capability. Since she didn't seem to understand much of the text, it was understandable that some parts of her translation were incomprehensible and totally unacceptable.

\subsubsection{Problem-solving strategies}

Two problematic segments have been selected here to compare the ways in which the three subjects tackled the problems. One is the segment imported disinflation, which has been identified as the most difficult to translate by the subjects. The other is the segment should (concentrate minds): about half the subjects identified it as problematic. They have been chosen because they present different kinds of translation problem. (Appendix 3 provides the protocols for the processing of these items by the subjects.)

\section{Imported disinflation}

The three subjects produced the following translations for this item. (The back translations are given in the parentheses.). It can be seen that Pro's translation is similar to the ST segment in form, but it deviates a little from the original sense with its nuance of "the U.S. government taking positive measures." (This was not counted as a semantic error, however.) On the other hand, TS's translation is far from the segment on the surface, and yet it delivers the message quite clearly. LL's translation is incomprehensible.

$$
\begin{aligned}
& \text { Pro: 이 들 지역을 활용하는 인플레 해소책 } \\
& \text { (anti-inflationary measures which use these regions) } \\
& \text { TS: 외국으로부터의 값싼 수입품으로 인해 물가상승 압력이 낮아져 } \\
& \text { (with lower inflationary pressure thanks to cheap imports from foreign countries) } \\
& \text { Foreign countries from cheap imported products owing to inflation lower } \\
& \text { LL: 국내 시장의 통화팽창 압력을 저지할 수 있는 디스인플레이션을 포함한 } \\
& \text { (including disinflation which can contain inflationary pressure of the local market) }
\end{aligned}
$$

The subjects differed in some respects. Problem-solving strategies used by Pro and TS consisted of inferencing followed by dictionary search. LL's strategy, however, was limited to dictionary search. (As will be seen later, Pro and TS exhibited differences in terms of knowledge they used in making inferences.)

Pro didn't seem to know exactly what the segment meant. She dealt with imported and disinflation separately. She immediately came up with the interpretation 이들 지 
역에서 수입해온 (back translation: imported from these countries) for imported. Later, she checked this interpretation through parsing as shown in her protocol imported disinflation from $A, B, C$ (see Appendix 3). For disinflation, she seemed to have inferred meaning using linguistic clues: she might have guessed the term as meaning the opposite of inflation by morpheme analysis (dis+inflation). She then attempted to derive meaning in context by extending the scope of analysis to the sentence containing the item, and then the adjoining sentences, and then the rest of the text. After reading the whole text, she said it didn't help at all. Finally, she referred to a dictionary to check if the meaning inferred was right, and she decided to go ahead with her first interpretation. Here the basis for her inference was mainly her knowledge in English, although she sought clues from the text (albeit, in vain). It can be clearly seen that all along she was not quite sure of the adequacy of her interpretation. Unfortunately, she herself was not satisfied with her translation (as assessed by herself in the questionnaire) after all the lengthy processing (see Appendix 3).

For TB, comprehension of the ST item in question occurred rather easily. She treated the item imported disinflation as one chunk and inferred meaning based on her background knowledge. In a word, she had no difficulty understanding this item. Rather, she was concerned with how it would be rendered most adequately in the target language, Korean. Specifically, she hesitated between the literal target equivalent, 수입된 디스인플레이션, and a simpler explanation of the term. After doing a dictionary search, she decided upon the latter, saying that no equivalent Korean term was shown. This decision was guided by her thinking that the target readers would include the general public, who might not be able to understand the specialized target term 수입 디스인플레이션. It can be seen that, basically, her problem was of production (rather than comprehension) type as was commented by her in the questionnaire. The protocol shows that her comprehension processing was brief and concise (see Appendix 3): she used only her background knowledge related to the problematic item, and her translation was satisfactory (she said so in the questionnaire).

LL first tried to recall disinflation, saying that she had learned something like inflation and deflation before (see Glahn 1980 cited from Krings [1986: 270], for retrieval from learning situations). She then looked it up: first in a bilingual dictionary and a dictionary of economic terms and tried to understand the term (by reading the entries and the term description). Without understanding the item fully and without further attempting to understand it, she adopted the transliteration 디스인 플레이션. As for imported, she tried to figure out meaning, giving 의미있는(meaningful) and 포함한(including) as candidate interpretations. She somehow associated it with the word with before the item ('with' imported disinflation) and decided to translate it into 포함한, which of course was an off-target translation. Throughout the process, she exhibited little concern for the exact meaning of the term or perhaps, was simply unable to capture the meaning. Her strategy was restricted to dictionary search and her processing remained at a linguistic level. Furthermore, the scope of her analysis was limited to the sentences containing and surrounding the item. Her final translation didn't make sense.

\section{Should}

The final translations of the segment should (concentrate minds) produced by the three subjects are provided together with the back translations. They all interpreted it as 
denoting "necessity" as it should be. According to the think-aloud protocols, Pro and LL didn't recognize should as a problematic item at all. (In the questionnaire, Pro marked should as unproblematic, whereas LL marked it problematic.) Therefore, the analysis is restricted to TS.

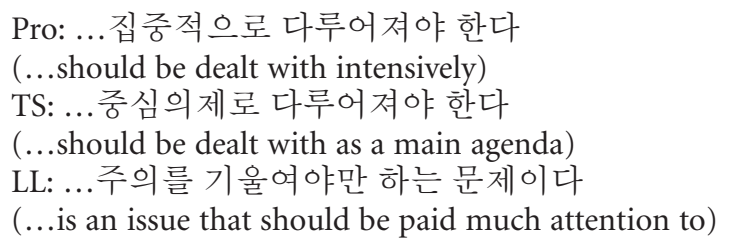

TS immediately identified should as problematic and decided to wait until the meaning clarified itself in context as the text proceeded. After the first translation, she came back to the problem. She seemed to lean toward "certainty" rather than "necessity," and she provided three target variations. Her final translation of the item, however, was rendered as meaning "urging the politicians to do some action" (necessity). The questionnaire and the telephone conversation with her revealed that she changed her mind after reading the rest of the text closely. Thus, her decision-making was based on information from the text, that is, textual knowledge.

\subsubsection{Use of reference material}

The three subjects differed in their use of reference material in terms of frequency and nature. Pro used a bilingual dictionary and a monolingual dictionary four times: once for the unknown item splutter at the stage of comprehension and three times for double-checking the items disinflation, powers ahead, export its way out of trouble while monitoring, whose meanings she had inferred first. It should be noted that although she did not know the exact meaning of splutter, she was able to infer meaning correctly from the surrounding context. She didn't refer to other materials except the dictionaries.

TS used the Internet for reference. First, she looked up the item brush aside in a bilingual dictionary, but did so only after she inferred the meaning by herself. She also searched for imported disinflation on the Internet, which was for an adequate target rendering and not for meaning establishment. Other than these two instances, no other use of resource materials was observed in her protocol. And yet, she said in the questionnaire that she also used the search engine Google on the Internet.

LL relied heavily on dictionaries and other reference materials both for understanding and reformulation. For the most part, she used a bilingual dictionary, and sometimes a monolingual dictionary as well as a dictionary of economic terms. She seemed to resort to dictionaries for almost every unknown lexical item, even looking up words she knew, probably to double-check on meanings retrieved from memory (not 'inferred' from context or other ways). Sometimes, she used a dictionary instead of intuition, while monitoring the correctness of target equivalents found. She also consulted parallel Korean texts to find appropriate target renderings. She even asked for help from her father and her boyfriend, who were not experts on the subject matter. LL's behavior points to a lack of confidence on her part.

In short, the use of reference material by Pro and TS was rather limited. Further, they first inferred meaning before using a dictionary, which was used mainly to 
double-check the inferred meanings. In contrast, LC used various reference materials excessively for both unknown and known items, and for both understanding and production.

\section{Discussion}

The present study addressed two questions regarding the use of extralinguistic knowledge in translation, and the questions are repeated here: (1) How important is extralinguistic knowledge relative to other components or elements of translator competence?;

(2) How is extralinguistic knowledge used or in what way is it important in understanding an ST?

With regard to the first question, data analysis revealed that expert or specialized knowledge, which is part of extralinguistic competence, was a more significant predictor of the success of translation compared to linguistic knowledge. Specialized background knowledge about the subject matter of an ST makes the translation process easy, concise, and efficient, leading to a higher quality translation. This is evidenced in the performance of two translators (one was observed in the questionnaire and the other in the think-aloud study), who were well versed in the subject matter in question and produced perfect translations without much difficulty and effort. On the other hand, a lack of this knowledge makes the process difficult, lengthy, and inefficient, and could lead to a lower-quality translation (as was shown by a professional translator in the think-aloud study).

Another important element found to contribute to producing good translation is "translation effort." It can be recalled that two language learners conveyed the accurate message in their translations despite deficient vocabulary and subject-matter knowledge. This was the result of tremendous effort (including extensive subject research) focused in the right direction, which made up for the overall low competence. The concept of translation effort has not drawn much attention in translation studies. Kim (2001), however, found that a professional translator made great efforts, as exhibited by a variety of strategies and complex cognitive processes, to find the most appropriate translation equivalents. This was in marked contrast to a language learner in the study who had tried limited strategies such as a dictionary search and a structural analysis, or had sometimes even given up translating. Gerloff (1986) also attributed the success of one of his subjects with particular problem passages to his high level of personal involvement with the text (along with others).

It is understandable that the overall level of translator competence is in proportion to the overall level of translation quality. This does not seem to apply in every translation situation, however. Recall that the translations produced by a few professional translators were either not as good or about the same as those done by some language learners. This was a rather unexpected result considering that the former were much better at English, more familiar with the subject matter, and had more field experience as a translator. One possible reason for this is that there is a threshold level of competence in every element required to ensure a good translation. However competent in language and however experienced in translating, one cannot produce a good translation without expending a certain minimal level of translation effort. It is hoped that this finding adds to understanding the nature of translator competence. 
In relation to the second research question, three important findings emerged from the think-aloud study. First, the strategy of inferencing was used in addition to the dictionary search in efficient and successful translation. Second, comprehension problems could best be solved by inferencing based on extralinguistic knowledge rather than linguistic knowledge. Third, the type of knowledge most relevant in making inferences varied in accordance with the type of problems.

Inferencing appears to be a major strategy used by competent translators in comprehending a text. In this study, when the professional translator (Pro) and the translation student (TS or the semi-professional translator) encountered a problematic ST item, they first tried to infer meaning instead of and/or before doing anything else. And, this was observed for almost every problematic item for both translators. On the other hand, the language learner (LL) had a strong tendency to use a dictionary whenever possible. She might have had no other choice, since her linguistic and extralinguistic knowledge were insufficient. A word of caution here: it is not certain whether a specific strategy is better, or whether one order of strategy use is superior to others. That is, no causal relationships can be established yet between the strategy use and the product. Rather, knowing when and how to use what strategy in a specific case seems to be a vital skill for the translator.

For the ST item imported disinflation, TS came up with accurate and adequate translation, while Pro's translation diverged a bit from the item. (LL produced a nonsensical translation.) Pro and TS showed commonality in inferring meaning for this item, but they differed in one important respect: Pro did 'linguistic' inferencing and TS did 'extralinguistic' inferencing. To be specific, Pro's inferencing was mainly based on linguistic analysis using her knowledge of the language (English), whereas TS's inferencing was based on her prior background knowledge of the economic world. Furthermore, Pro was not sure of the inferred meaning and struggled for quite a while to find an adequate interpretation from the text. Unfortunately, her comprehension of the item was incomplete. Unlike Pro, TS grasped the meaning of the term thoroughly as being associated with the concept she is familiar with. She was sure of her interpretation and so proceeded with her processing in a concise and confident manner. This confidence might have allowed her to concentrate more on the target rendering. As could be expected, TB's target rendering of the item was easy to understand and more to the point. (TS's choice of the target translation based on the TT recipients shows a macro-level approach involving text awareness (Jonasson 1998) or control by translation-expectation structures (Kiraly 1995).)

This finding suggests that background knowledge or extralinguistic knowledge supercedes linguistic knowledge in solving comprehension problems in translation. This is so because it enables a translator not only to do deeper-level comprehension processing but also to do such processing in an efficient, economical, and confident way, leaving much room for other types of processing.

As regards the third finding, the problem of imported disinflation was best solved by TS by using her specialized background knowledge related to it. So, inferencing based on "extratextual" knowledge was more efficient than language-based inferencing for this item. On the other hand, it was "textual" knowledge (i.e., information derived from the text) that was useful in solving the grammatical problem of should. The type of problem at a local level, or the type of text at a global level, seems to correlate with the type of knowledge to be utilized. If a translator has knowledge which 
is most relevant to solving a specific problem, using that knowledge should be the simplest and most efficient way of solving it (i.e., an optimal solution). In short, the importance of extralinguistic knowledge as an inference-based problem-solving resource in translation cannot be denied. What matters is not the knowledge per se but the relevancy of the knowledge accessed to solve a specific translation problem. It is the knowledge base a translator has and the type of knowledge a translator chooses that determines the quality of translation.

Besides the findings discussed above, one striking difference in the subjects' behavior should also be mentioned. It concerns the use they made of dictionaries. Pro and TS consulted them only on a few occasions, whereas the language learner used them quite heavily. More importantly, the former used dictionaries "not for establishing meaning but as a stimulus to the process of refining meaning and selecting an appropriate rendering" (Fraser 1996: 72). In contrast, the main purpose for the language learner to use dictionaries was to search for meaning. This finding replicates the previous findings. A new finding of the study is that the translators tend to make inferences using all knowledge available before turning to dictionaries, and they used dictionaries as the last resort or an additional aid. On the contrary, dictionaries were the first and foremost choice for the language learner.

The lack of self-confidence seems to underlie the language learner's excessive reliance on the bilingual dictionary (for comprehension of the source language) and the Korean parallel texts (for reformulation in the target language). Fraser (1995) points out that self-confidence brings with it the ability to tolerate ambiguity involved in successful translation. Teachers need to help students refrain from using dictionaries too much and move their focus toward developing strategies for extracting and assessing meaning and finding and selecting an appropriate target rendering. They also need to help them build their self-confidence. Confidence can come from years of experience, or it might be a matter of personality. If the latter is the case, it is all the more important that curricula are developed so that every student has one or two specialized fields in which s/he feels most confident. One such curriculum can be found at the École d'Interprètes Internationaux in Belgium, where students learn a range of specialized knowledge from the various university departments (Klein and Lovenberg 1999). In this way, one can kill two birds with one stone - acquisition of extralinguistic, specialized knowledge and self-confidence at the same time.

\section{Conclusion}

In conclusion, it should be remembered that better language proficiency does not always lead to higher translation quality. Also, more experience, thus, overall higherlevel translator competence, does not necessarily correlate with better translation, either. Expert or specialized background knowledge is perhaps by far the most important element in the translator competence, as is indicated in the remark: "[...] the best translations are produced in cooperation between professional translators who are also linguists and experts in the subject matter of the text" (Tirrkonen-Condit 1992: 440). Equally important is deeper involvement with the task or translation effort, which can guarantee you a good (though not always perfect) translation. The results of the study are not yet conclusive due to the small amount of data and the limited scope. Future studies will decide whether they are applicable to other subjects, 
other texts types, other translation problems, other language directions and combinations. For now, the job of a translator is to maintain an interest and curiosity in things around him/her and make a continuous effort to be equipped with encyclopedic knowledge. Such knowledge will eventually come in handy in one way or another.

\section{NOTES}

1. Extralinguistic knowledge can be further divided into textual knowledge and extratextual knowledge. Textual knowledge is knowledge extracted from the text at hand. Extratextual knowledge is all knowledge a translator has including general world knowledge, expert knowledge, background knowledge, the subject matter knowledge, etc. (Tirrkonen-Condit 1992).

2. Dancette (1997) didn't mention the term "deverbalization" (Seleskovitch 1977) explicitly. However, ST understanding at the notional level seems to imply the process of deverbalization, by which the meanings of the segments are made explicit, being separated from the forms used.

3. The questionnaire distributed to the subjects had more questions than the one in Appendix 2. Only those questions that were used and so relevant in the study are presented in Appendix 2. The questions were very similar to those which appeared in the questionnaire presented by Orozco and Albir (2002).

4. The problematic segments contained in the questionnaire were selected on the basis of a linguistic analysis of the ST by the researcher.

5. The translation with the meaning of "certainty" for this item was not counted as an error as long as it did not undermine the message of the ST in any significant way.

\section{REFERENCES}

Dancette, J. (1997): “Mapping Meaning and Comprehension in Translation,” In J. H. Danks, G. M. Shreve, S. B. Fountain and M. K. McBeath (Eds.), Cognitive Processes in Translation and Interpreting, London, Sage Publications.

Fraser, J. (1993): "Public Accounts: Using Verbal Protocols to Investigate Community Translation," Applied Linguistics 14, p. 325-343.

Fraser, J. (1995): “Professional versus Student Behavior,” In C. Dollerup and V. Appel (Eds.), Teaching Translation and Interpreting 3: New Horizons, papers from the third language international conference, Philadelphia, John Benjamins.

Fraser, J. (1996): “The Translator Investigated: Learning from Translation Process Analysis," The Translator 2, p. 65-79.

Gerloff, P. (1986): “Second Language Learners' Reports on the Interpretive Process: Talk-aloud Protocols of Translation," In J. House and S. Blum-Kulka (Eds.), Interlingual and intercultural communication: Discourse and cognition in translation and second language acquisition studies, Tübingen, Gunter Narr Verlag.

Gile, D. (1995): Basic Concepts and Models for Interpreter and Translator Training, Philadelphia, John Benjamins.

Glahn, E. (1980): "Introspection as a Method of Elicitation in Interlanguage Studies," In Interlanguage Studies Bulletin 5, p. 119-128.

JäÄskeläInen, R. (1990): Features of Successful Translation Processes: A Think-aloud Protocol Study, licentiate thesis, Savonlinna School of Translation Studies, University of Joensuu.

JonAsson, K. (1998): "Degree of Text Awareness in Professional vs. Non-professional Translators," In A. Beylard-Ozeroff, J. Králová and B. Moser-Mercer (Eds.), Translator's strategies and creativity, Amsterdam/Philadelphia, John Benjamins.

KIm, R. (2001): "The Cognitive Processes of English-Korean Translation by a Translator and a Language Learner," Conference Interpretation and Translation 3, p. 59-86.

Kiraly, D. C. (1995): Pathways to Translation: Pedagogy and Process, Ohio, The Kent University Press.

KLein, J. and F. Lovenberg (1999): “Multidisciplinarity and Translation," Linguistica Antverpiensia 33, p. 101-112. 
Krings, H. P. (1986): "Translation Problems and Translation Strategies of Advanced German Learners of French (L2)," In J. House and S. BLum-KulKa (Eds.) Interlingual and Intercultural Communication: Discourse and Cognition in Translation and Second Language Acquisition Studies, Tübingen, Gunter Narr Verlag.

Laukkanen, J. (1996): "Affective and Attitudinal Factors in Translation Processes," Target 8, p. 257 274.

Lehmann, V. (1986): "Understanding in Translation and in Foreign Language Teaching: Inferencing Based on Verbal and Aspectual Meaning," In J. House and S. Blum-KulKA (Eds.), Interlingual and Intercultural Communication: Discourse and Cognition in Translation and Second Language Acquisition Studies, Tübingen, Gunter Narr Verlag.

Lörscher, W. (1993): “Translation Process Analysis," In Y. Gambier and J. Tommola (Eds.), Translation and Knowledge (SSOTT IV Proceedings), Turku, University of Turku Press.

Orozco, M., and A. H. Albir (2002): “Measuring Translator Competence Acquisition," Meta 473, p. 375-402.

Seleskovitch, D. (1977): “Take Care of the Sense and the Sounds Will Take Care of Themselves or Why Interpreting is not Tantamount to Translating Languages," The Incorporated Linguist 15, p. 27-33.

TirkKonen-Condit, S. (1988): “Interpretation of meaning in translation," In L. Laurinen and A. Kauppinen (Eds.), Problems in language use and comprehension, Helsinki, AfinLa.

Tirkkonen-Condit, S. (1989): "Professional vs. Non-professional Translation: A think-aloud Protocol Study," In C. Seguinot (Ed.), The Translation Process, School of Translation, Glendon College, York University, H.G. Publications.

Tirkкonen-Condit, S. (1992): "The Interaction of World Knowledge and Linguistic Knowledge in the Process of Translation: A Think-aloud Protocol Study," In M. Thesen and B. LewandowsKaToмAzсzyк, Translation and Meaning II, Maastricht, Tykswgeschoot Maastricht.

\section{Appendix 1}

\section{THE ENGLISH SOURCE TEXT}

\section{Sagging euro}

There is little that the European Central Bank can or should do about the weakness of the euro. But the new currency's slide should concentrate minds at today's European Union summit.

The euro yesterday touched a new low against the dollar, more than 11 percent below its launch value. This largely reflects the weakness of the euro-zone economy. While the US has brushed aside the effects of Asian, Russian and Latin American economic troubles - with imported disinflation helping to contain inflationary pressures as the domestic economy powers ahead - the euro-zone is spluttering.

The euro's drop will do nothing to help morale at the ECB. Nor will European politicians be pleased by US complaints that Europe is shirking its responsibilities and trying to export its way out of trouble.

However, with economy activity so weak - particularly in Germany and Italy which make up half of the euro-zone - and with no sign of a falling euro feeding into inflation, the ECB can hardly raise interest rates. Yesterday it lifted its benchmark rates unchanged at 2.5 per cent (an overly keen employee posting the decision on the internet five minutes before it was officially announced). With Europe so weak, depreciation is at least providing some relief for exporters. The US is likely to complain again at this month's Group of Seven meeting that Europe is not pulling its weight. But there is nothing the ECB can sensibly do.

Therefore, it should stop worrying in public about the falling exchange rate. If the euro hits parity with the dollar, so be it. The alternative is intervention in the market to support the euro by selling dollars. Wim Duisenberg, ECB president, yesterday left open the door for $\mathrm{ECB}$ attempts to buck the market. But this is unlikely to work as long as US rates are set to 
rise and European rates to stay on hold. Bungled, unco-ordinated attempts to talk up the euro have done more harm than good. So would failed intervention.

Patience is the better option. As the euro-zone growth recovers, the currency will rise. The enormous US current account deficit is eventually likely to send the dollar lower.

It is now time for the politicians, not the bankers to do their part. At today's summit, EU leaders should commit themselves to structural reforms rather than wasting time with notional growth and employment targets.

It is clear that promises are useless without action, and that liberalization will involve short-term costs. But a credible commitment to greater flexibility is needed to restore investors' faith in Europe's economy and in its currency.

APPENDIX 2

\section{QUESTIONNAIRE 1: GENERAL BACKGROUND}

Name: Years of Experience:

Do you have specialized areas in translation? yes no

If yes, what are your specialized areas?:

\section{How would you rate yourself? Circle the number.}

I have interest and knowledge in current affairs.

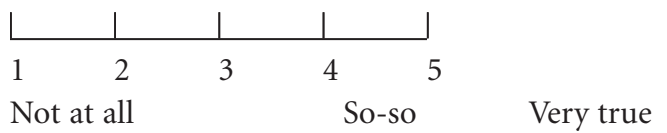

2. I am familiar with the subject matter of this news article.

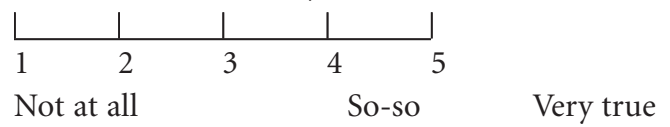

3. I know most of the words and expressions in the article.

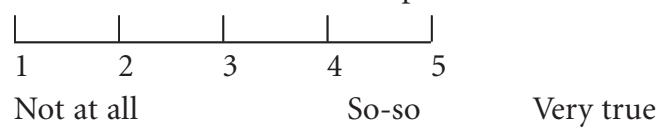

4. I put a lot of time and effort into translating this article.

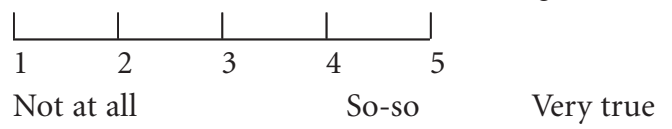

5. I understand what 'translation' is.

$\begin{array}{llllll} & & & & \\ \\ 1 & 2 & 3 & 4 & 5 & \\ \text { Not at all } & & \text { So-so } & \text { Very true }\end{array}$

II. List the five most difficult problems that you had in the order of difficulty and answer the following questions, describing what kind of problems they were and how you solved them.

\section{Problem:}

Do you think you have solved the problem? No Yes What did you do to solve it? 


\section{Was each of the following segments a translation problem?}

$\begin{array}{lll}\text { A. "slide" (line 2) } & \text { Yes } & \text { No } \\ \text { B. "should (concentrate minds)" (line 2) } & \text { Yes } & \text { No } \\ \text { C. "concentrate minds:" (line 2) } & \text { Yes } & \text { No } \\ \text { D. "touched a new low" (line 4) } & \text { Yes } & \text { No } \\ \text { E. "launch value" (line 5) } & \text { Yes } & \text { No } \\ \text { F. "brush aside" (line 6) } & \text { Yes } & \text { No } \\ \text { G. "imported disinflation" (line 7) } & \text { Yes } & \text { No } \\ \text { H. "powers ahead" (line 8) } & \text { Yes } & \text { No } \\ \text { I. "export its way out of trouble" (line 12) } & \text { Yes } & \text { No }\end{array}$

\section{Appendix 3}

\section{THE PROTOCOLS FOR THE PROCESSSING OF IMPORTED DISINFLATION AND SHOULD}

\section{Pro's processing of imported disinflation:}

$1^{\text {st }}$ translation:

그리고 그 방법으로서는 이들 지역에서 수입해온, 이들 지역에서 들여온, disinflation (reading ST) 인플레이션을 없애는 거니까, 인플레 해소, 이 들 지역으로부터의 인플 레 해소가, 인플레를 해소하는 것이, contain inflationary.(reading ST) 인플레 압력을 억 제하는데, 인플레 해소를 도입함으로써 인플레 압력을 억제하는데 도움을 받고 있 습니다. 미국의 국내경제, 국내경제는, powers as the domestic economy powers ahead 국 내경제가, 약진, 앞으로 약진할 것 같습니다. 여기가 조금 아이디어가 분명치 않은 데요. The euro zone is 반면에 미국이 이렇게 비교적 잘 해 내가고 있는 반면에 유로 화가 통용되고 있는 지역의 경제, 지역은 spluttering

\section{Returning to the problem after $1^{\text {st }}$ translation:}

근데 잘 안 되는 것이 문제가 되는 것이 미국과 유럽의 경제상황이 with imported disinflation helping to contain inflationary pressures as the domestic economy powers ahead (reading ST), 요 부분의 의미가 분명하지 않아서 그런 것 같아요.imported disinflation (reading ST) 인플레이션이 진행이 되는데, 그 것을 폐지하고 없애는 그런 것들이, 근거가 외국에서부터 들어온다는 거죠. 그거는 아까 열거된 고 바로 위에서 열거된 아시아, 러시아, 남미 요 세 지역으로부터 (silence) 이 지역의 경제문제의.. 여파로 brush aside 솔질해서 씻어, 쓸어버리고, 쓸어버리고 있는 반면에 유럽지역의 경제는 유럽은 유로화가 통용되고 있는 지역은 질척거리고 있다. 이렇게 되는 거거든요. 대 조가 되어 있는 데 with imported disinflation helping to contain inflationary pressure 이것도 분명하죠 이것도 분명하죠. 인플레 압력을 억제하다 하는데 도움을 준다 그런데 imported disinflation 수입된 인플레 억제효과여기가 지금 아이디어가 분명하지 않거 든요. As the domestic economy powers ahead 여기서는 사전이 필요한 것 같습니다.

그 부분이 이해가 안.. disinflation 이 제가 생각하는 대로 인플레를 해소하다이런 뜻 인지 분명하게 찾아보려 그러구요. 사전을 안 찾기 때문에 굉장히 좀 느립니다. 인 플레이션 상태에서 정상적인 수준으로 돌아오는 과정으로 되어있습니다. 제가 갖고 있는 의미하고 별로 다르지 않은 것 같은데요. 인플레를 해소해 가는 과정이 아까 말했다시피 imported 니까 아까 세 개 지역으로부터 이런 것들이 들어온다는 거죠. 삽입구가 with 해외에서 도입된 요인에 의한 인플레 안정과정 인플레 해소과정이 인플레 압력을 억제하는데 도움이 된다. 그런데 도움을 주는 상황이

일단 번역을 마치겠습니다. 일단 초벌 여기를 이해했기 때문에 그러면 뒤를 이해하 려고 해보겠습니다.

근데 문제는 이 뒤 부분이 아까 것을 이해하는데 큰 도움이 되지 않는다는 겁니다. 
$2^{\text {nd }}$ Translation:

미국이 아시아, 러시아, 남미 경제지역의 문제로 인한 영향을 brushed aside 유로지역 은 횡설수설하고 그런데 여기다 마찬가지로 수입된 해외 발 인플레이션 해소과정 아니면 인플레 안정화 과정이 국내의 $\cdots$ 지금 미국 국내경제가 굉장히 약진해 나가 는 추세에 있다는 거죠 약진해 나가고 있으면 그렇게 되면 물가 상승이 생기고 그 러면 인플레 압력이 가중되죠 이걸 해결하는 과정으로 imported disinflation from $A, B$, and $C$ 이렇게 될 것 같은데.

$3^{\text {rd }}$ Translation:

미국은 아시아, 러시아, 남미경제지역의 문제점들을 털어내고 이 들 지역으로부터 도입된 인플레 안정화효과로 국내경기가, 국내경기의 약진이 예상되고 있는 가운 데 가중되는 인플레 압력을 억제하는데 도움을 받고 있습니다. 그러나 반면 유로존 에서는 갈팡질팡하고 있습니다.

\section{TS's processing of imported disinflation:}

그 다음에 여기 삽입부분은 이유일 테니까 그걸 그렇게 처리하면... (silence while reading ST) 음.. imported disinflation이니까 이게 중국 같은 데가 인플레이션을 수출 한다라는 애기를 많이 하니까 결국 이게 그 애긴 것 같은데.. 그러니까 외국으로부 터 값싼 수입품이 많이 몰려와서 물가상승에 도움을 주었다는 애기 같은데.. 이걸 수입된 디스인플레이션 이라기 보다 풀어서 써야 하지 않나? 찾아볼까? 여기를? (searching in a dictionary) imported disinflation (typing) 안 나오나? 안 나온다. 그낭 풀 어서 써줘야겠다. 외국으로부터의 값싼 수입품...(silence) 이걸 앞으로 가져가야겠 다. 외국으로부터 값싼 수입품으로 인해 (silence)

\section{LL's processing of imported disinflation:}

(while typing) 이게 뭐더라. inflation, deflation이었나? disinflation 내가 예전에 경제를 열심히 배웠는데 기억이 안나(identifying a problem). (typing ST) .....

with imported disinflation (reading ST), disinflation 이거나 봅시다. (searching a dictionary) 디스플레이션이라고 그냥 쓰는 것 같은데. 디스인플레이션을 초래하지 않을 정도 의 완화가 디스인플레이션이래. 그러면 디스인플레이션을 경제용어로 찾아봐야겠 지. 디스인플레이션. 나왔다. 물가상승율이 높은 상태에서 낮은 상태로 이행해 가는 과정, 또한 그런 과정을 이그는 과정을 말한다. [...]제 2 차 석유 쇼크에서 이 현상은 각국이 긴축정책을 실시했고 진정 등에서 비롯된 소비의 저조에서도 영향을 받을 수 있다. (reading the explanation in the dictionary)

어쨌든 그냥 디스인플레이션이라고 쓰면 된다. 그 애기지, 근데 imported해? 디스인 플레이션을. Helping to contain inflationary pressures as the domestic economy powers ahead (reading ST) 그러나 미국은(pause) 국내시장, domestic economy powers ahead (reading ST) (silence)

spluttering(typing, searching in a dictionary) 흥분하여 말하다(reading the explanation), 응. 그러나 미국은 유럽연합이 말하는, 아니야, 유럽연합이 주장하고 있는 국내시장 의 인플레이션, 인플레이션을 경제팽창, 찾자, 왜 없지? 아, 여기 없네. 이런. 사전에 서...., 인플레의 통화팽창의, 통화팽창압력이 낫겠다. 국내시장의 통화팽창 압력을 포함하여, 그러나 미국은 국내시장의 통화팽창 압력을... (sighing) 아. 이거 빼버리 고 싶다. 무슨 말인지 모르겠는데. 찾아보자. (typing).

imported disinflation helping to contain (reading ST) 여기서는 helping이 조력, 원조라고 쓸 수 있다고 되어 있는데, 그렇다고 disinflation 도움을. 그렇게 되나? disinflation 다 시 한번 봅시다. disinflation (typing). 이건 그냥 명사잖아, 명사 뒤에 바로 명사가 올 수 없어. 그렇다면 애는 형용사야. (sighing) helping to (reading ST) 유럽연합이 주장 하고 있는 국내시장의 통화팽창 압력을,

아휴, contain이 포함하다 말고 다른 뜻이 되어야 하는데. 국내시장의 통화팽창 압력 을(silence) 저지하다? 저지하는 것을 돕는 디스인플레이션의, 의미하다? 돕는 imported니 
까 그냥 의미있는? imported 다시 볼까? imported 저지하는 것을 돕는, 의미있는 디스 인플레이션을, 이니까. 그냥 imported 뺄까?

그러나 미국은 유럽연합이 주장하고 있는 국내시장의 통화팽창 압력을 저지하는, 돕는 빼자. 저지하는 디스인플레이션을 포함한 아시아, 러시아, 그리고 라틴 아메리 카의 경제문제의 역할을 무시하고 있다. 이게 좋을 것 같아. 왜나하면 with 가 ..와 함께라고 할 수도 있지만 이거를 포함하다라고 생각할 수도 있으니까 포함한이라 고 하면 될 것 같고. Imported 미국은 유럽연합이 주장하고 있는 splutter는 계속 말 을 하다...

\section{TS's processing of should:}

$1^{\text {st }}$ translation:

should를 어떻게 번역해야 되나? (identifying the problem) 일단 일단 볼드로 남겨 두 고 나중에 맥락을 좀 봐야겠네 (planning problem-solving strategy). 볼드스타일로 해 놓고... 다음 문장으로 넘어가서 (silence)...

$2^{\text {nd }}$ translation:

볼드부분으로 되어있는 concentrate minds at. But the new currency's slide should concentrate minds (reading ST) should 여기서 should는 당위성보다는 그낭 미래에 이러할 것이다 라는 애기를 지금 하는 것 같은데 그냥 그렇게 가야 할 것 같은데. 아니면 초유의 관심사가 될 것이다 정도? 집중논의가 될 것이다 정도? (pause) 중심의제가 될... (silence) 